\title{
SERAPAN KARBON LAMUN Thalassia hemprichii PADA BEBERAPA KEDALAMAN
}

\section{Carbon Sequestration of Sea Grass Thalassia hemprichii at Various Depths}

\author{
Supriadi Mashoreng ${ }^{1 *}$, Sheryl Alprianti ${ }^{1}$, Wasir Samad ${ }^{1}$, Rantih Isyrini ${ }^{1}$, Dwi Fajriati Inaku ${ }^{2}$ \\ Diterima: 28 Juni 2019 Disetujui: 10 Juli 2019
}

\begin{abstract}
ABSTRAK
Ekosistem padang lamun merupakan ekosistem yang umum ditemukan di Kepulauan Spermonde, salah satunya adalah Gusung Bonebatang. Lamun mempunyai kemampuan menyerap karbon untuk proses fotosintesis sehingga berpotensi dalam mitigasi perubahan iklim. Penelitian dilakukan pada bulan Agustus 2017 untuk membandingkan penyerapan karbon oleh jenis Thalassia hemprichii pada beberapa kedalaman perairan. Sampel lamun diambil pada daerah subtidal, kemudian daun lamun dibersihkan dari sedimen dan epifit. Metode perubahan oksigen digunakan untuk mengestimasi serapan karbon. Sebanyak 1 tunas T. hemprichii diinkubasi menggunakan botol kaca bening $70 \mathrm{ml}$. Inkubasi dilakukan pada jam 09.00-12.00 WITA pada kedalaman 50, 100, 150, 200 dan $250 \mathrm{~cm}$ dengan masing-masing 5 kali ulangan setiap kedalaman. Sebelum inkubasi, dilakukan pengukuran konsentrasi oksigen terlarut di perairan sebagai kandungan oksigen awal. Pengukuran oksigen di dalam botol bening kembali dilakukan setelah inkubasi. Selain oksigen terlarut, dilakukan juga pengukuran konsentrasi bikarbonat pada awal dan akhir inkubasi. Sebagai kontrol, inkubasi juga dilakukan pada air laut (mengandung fitoplankton) dengan 5 kali ulangan. Daun lamun yang telah digunakan untuk pengamatan serapan karbon diukur luasnya dengan cara men-scan daun lamun dan dianalisis menggunakan software Imaje-J. Selanjutnya dilakukan pengeringan menggunakan oven dan ditimbang untuk mengetahui biomassa keringnya. Hasil penelitian menunjukkan bahwa serapan karbon per tunas berkisar antara 0,928$1,476 \mathrm{mgCO}_{2} /$ tunas/jam, per biomassa berkisar 10,647-25,745 $\mathrm{mgCO}_{2} / \mathrm{gbk} / \mathrm{jam}$, dan per luas daun berkisar 0,010-0,024 $\mathrm{mgCO}_{2} / \mathrm{cm}^{2} / \mathrm{jam}$. Serapan karbon tertinggi didapatkan pada kedalaman $200 \mathrm{~cm}$, baik serapan karbon per tunas, biomass maupun luas daun.
\end{abstract}

Kata kunci: bikarbonat, Gusung Bonebatang Makassar, karbondiokasida, pemanasan global, serapan karbon lamun, Thalassia hemprichii.

\section{ABSTRACT}

Seagrass ecosystems are ecosystems commonly found in the Spermonde Islands, one of which is Gusung Bonebatang. Seagrasses have the ability to absorb carbon for photosynthesis so that it has the potential to mitigate climate change. The study was conducted in August 2017 to compare carbon sequestration by the type of Thalassia hemprichii in several depths of water. Seagrass samples were taken in the subtidal area, then seagrass leaves were cleaned of sediment and epiphytes. The oxygen change method is used to estimate carbon absorption. One T. hemprichii shoot was incubated using a 70 ml clear glass bottle. Incubation was carried out at 09.00-12.00 WITA at depths of 50,100,150, 200 and $250 \mathrm{~cm}$ with 5 replications each depth. Before incubation, measurements of dissolved oxygen in the water were measured as the initial oxygen content. The measurement of oxygen in the clear bottle is again carried out after incubation. In addition to dissolved oxygen, measurements of bicarbonate concentration were also carried out at the beginning and end of incubation. As a control, incubation was also carried out on seawater (containing phytoplankton) with 5 replications. Seagrass leaves that have been used to observe carbon uptake were measured by scanning seagrass leaves and analyzed using Imaje-J software. Then the oven was dried and weighed to find out the dry biomass. The results showed that carbon absorption per shoot ranged from 0.928-1,476 mgCO2 / shoots / hour, per biomass ranging from 10.647-25,745 mgCO2 / gbk / hour, and per leaf area ranged from 0.010 to $0.024 \mathrm{mgCO} /$ $\mathrm{cm} 2 /$ hour. The highest carbon uptake was found at a depth of $200 \mathrm{~cm}$, both carbon uptake per shoot, biomass and leaf area.

Key words: bicarbonate; Gusung Bonebatang Makassar; carbondioxide; global warming; seagrass carbon uptake; Thalassia hemprichii.

\section{PENDAHULUAN}

Lamun merupakan salah satu vegetasi pesisir yang tersebar di berbagai belahan dunia. Keberadaannya memberikan manfaat bagi lingkungan karena dapat berperan sebagai produser primer, tempat tinggal, tempat memijah dan membesarkan anak berbagai organisme (Gartside dan Smith, 2013), peran secara fisik sebagai pelindung pantai (Ondiviela, et. al., 2014), serta sebagai penyerap karbon (Duarte, 2013). Sebagai

\section{Korespondensi:}

Supriadi Mashoreng ${ }^{\text {* }}$

Email: smashoreng@ unhas.ac.id

${ }^{1}$ Departemen Ilmu Kelautan, Universitas Hasanuddin

${ }^{2}$ Departemen Perikanan, Universitas Hasanuddin tumbuhan yang merupakan salah satu produser primer, lamun menyerap karbon dalam proses fotosintesis dan menghasilkan oksigen. Dalam konteks pemanasan global, penyerapan karbon oleh lamun berkontribusi signifikan terhadap total serapan karbon vegetasi pesisir.

Beberapa penelitian menunjukkan pentingnya keberadaan padang lamun di wilayah pesisir dan pulaupulau sebagai penyerap atau pendeposit karbon (Huang et al., 2015; Marba et al., 2015; Lymo., 2016). Bahkan menurut dokumen tentang blue carbon yang dikeluarkan oleh tiga lembaga PBB (UNEP, FAO dan UNESCO), padang lamun bersama dengan mangrove dan salt marsh mampu menjadi garda penyeimbang 
bersama hutan untuk mengurangi laju emisi karbon melalui penyerapan karbon. Ketiga vegetasi pesisir tersebut, mampu menyimpan karbon laut ke dalam sedimen lebih dari separuhnya sementara luasnya kurang dari 0,5\% luaslaut secara keseluruhan. Khusus untuk padang lamun, karbon dari biomassa lebih rendah dibanding dengan hutan tropis, namun simpanan karbon pada sedimen lebih tinggi.

Jenis lamun di Indonesia tercatat sebanyak 13 jenis (Kuriandewa, 2009). Beberapa jenis lamun sangat mudah ditemukan karena toleransinya yang luas terhadap beberapa faktor fisika kimia perairan. Salah satu diantaranya adalah Thalassia hemprichii, yang merupakan lamun dengan sebaran yang luas di Indonesia. Pada banyak wilayah jenis lamun ini mempunyai kontribusi yang besar terhadap biomassa dan stok karbon (Mashoreng, 2017). Lamun $T$. hemprichii ditemukan mulai dari daerah intertidal bagian bawah sampai daerah subtidal. Walaupun mempunyai distribusi vertikal yang luas, namun diduga terdapat perbedaan kemampuan penyerapan karbon pada kedalaman yang berbeda. Oleh karena itu dilakukan penelitian untuk mengetahui kemampuan lamun T. hemprichii menyerap karbon pada beberapa kedalaman yang berbeda.

\section{METODE PENELITIAN}

\section{Waktu dan Tempat}

Penelitian lapangan dilakukan pada bulan Agustus 2017 di Gusung Bonebatang Kecamatan Kepulauan Sangkarang, Kota Makassar (Gambar 1). Analisis sampel dilakukan di Laboratorium Biologi Laut Fakultas Ilmu Kelautan dan Perikanan Universitas Hasanuddin. Gusung Bonebatang terletak sekitar $14 \mathrm{~km}$ sebelah barat daya Kota Makassar dengan posisi geografis $5^{\circ} 00^{\prime} 47.66^{\prime \prime}$ Lintang Selatan - 119 $19^{\prime} .35 .12^{\prime \prime}$ Bujur Timur. Padang lamun tumbuh di sekeliling Gusung Bonebatang kecuali pada sisi timur yang mempunyai perairan dalam dengan rataan terumbu yang sempit. Sebanyak tujuh jenis lamun ditemukan pada lokasi ini yaitu: Enhalus acoroides, Thalassia hemprichii, Halophila ovalis, H. minor, Cymodocea rotundata, Halodule uninervis dan Syringodium isoetifolium.

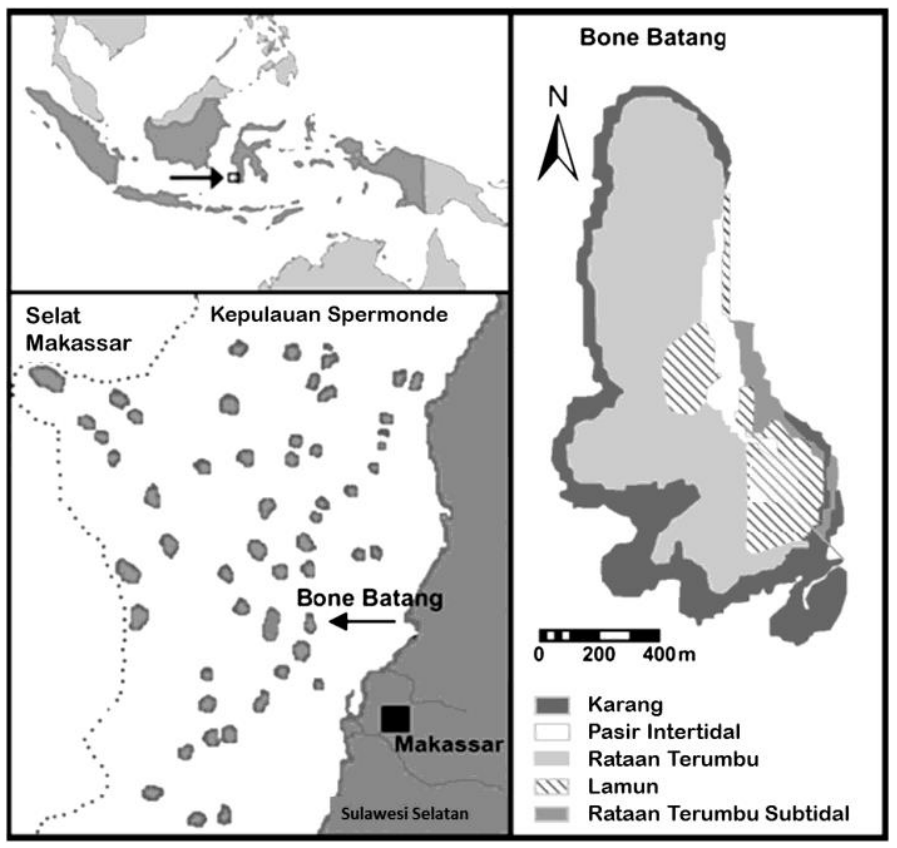

Gambar 1. Peta lokasi penelitian

\section{Bahan dan Metode}

Metode penyerapan karbon yang dilakukan adalah metode perubahan oksigen untuk mengetahui produktifitas primer menggunakan botol bening yang dimodifikasi dari Mateo et al. (2001) dan Silva et al. (2009). Lamun jenis T.hemprichii diambil dari daerah subtidal pada sisi barat gusung. Pengambilan dilakukan secara hati-hati sehingga akar, rhizoma dan daun terambil secara utuh. Daun lamun dibersihkan dari epifit dan sedimen yang melekat. Daun lamun dimasukkan ke dalam botol bening berkapasitas $70 \mathrm{ml}$ dengan menjepit bagian batang menggunakan tutup botol dari karet sandal yang telah dilubangi, sedangkan rhizoma dan akar lamun dibiarkan muncul ke luar (Gambar 2a). Setiap botol diisi sebanyak 1 tegakan lamun.

Sebelum ditutup, botol diisi dengan air laut. Pengisian air dilakukan di dalam air dan dihindari adanya gelembung udara yang dapat mempengaruhi konsentrasi oksigen sebelum botol diinkubasi. Sebelum botol yang berisi lamun diinkubasi, dilakukan pengukuran oksigen pada perairan dengan menggunakan metode titrasi Winkler (Parsons et al., 1984). Pengukuran parameter tersebut dilakukan 
sebanyak 5 kali ulangan. Kandungan oksigen ini dianggap sebagai kandungan oksigen awal.

Selanjutnya dilakukan inkubasi botol bening tersebut selama 3 jam (Mateo et al., 2001) dari jam 09.00-12.00 WITA, pada kedalaman $50 \mathrm{~cm}, 150 \mathrm{~cm}$ dan $250 \mathrm{~cm}$ dibawah permukaan air dengan masing-masing 5 kali

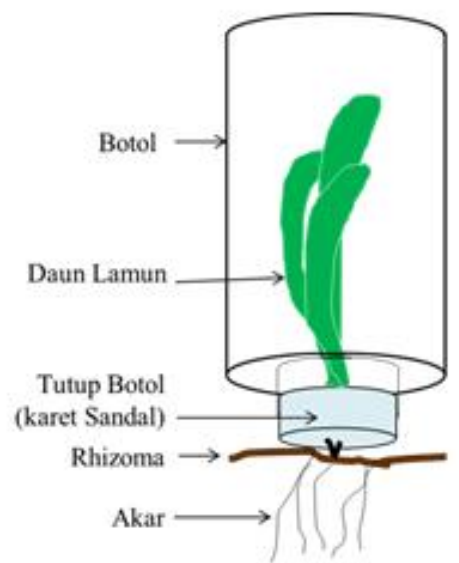

a ulangan (Gambar 2b). Selain untuk pengukuran oksigen terlarut, pada setiap kedalaman tersebut juga diinkubasi masing-masing 5 botol berisi air laut (mengandung plankton) sebagai kontrol dan faktor pengoreksi. Pada akhir inkubasi, dilakukan kembali pengukuran kandungan oksigen terlarut.

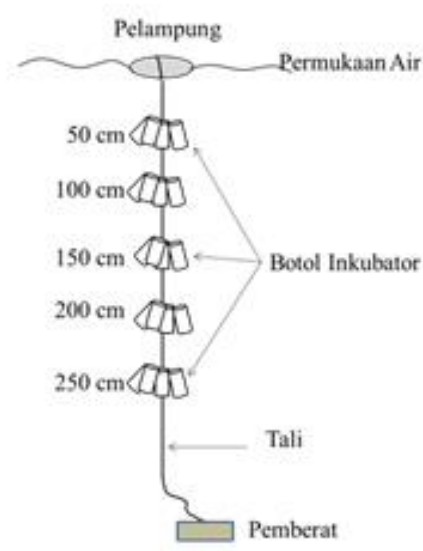

b

Gambar 2. Sketsa metode perubahan oksigen untuk mengukur serapan karbon lamun T. hemprichii. (a) Posisi lamun dalam botol bening, dan (b) posisi botol pada saat inkubasi di lapangan.

Nilai oksigen terlarut didapatkan dengan menggunakan formula sebagai berikut (APHA, 1995):

$O T=\frac{1000 \times \mathrm{A} \times \mathrm{N} \times 8}{\mathrm{Vc} x \mathrm{Vb} /(\mathrm{Vb}-6)}$

dimana :

$\mathrm{A}=\mathrm{mL}$ larutan baku natrium tiosulfat yang digunakan;

$\mathrm{Vc}=\mathrm{mL}$ larutan yang dititrasi;

$\mathrm{N}=$ kenormalan larutan natrium tiosulfat;

$\mathrm{Vb}=$ volume botol BOD

Produktivitas primer lamun diperoleh dengan menggunakan formula menurut APHA (1995) sebagai berikut :

$P P B=0,375 \times \frac{L B-I B}{N \times P Q}$,

dimana :

$\mathrm{PPB}=$ Produktivitas primer bersih $(\mathrm{mgC} / \mathrm{jam})$

$0,375=$ Faktor konversi dari oksigen ke karbon

LB = Kandungan oksigen pada botol bening $(\mathrm{mg} / \mathrm{l})$

$\mathrm{IB}=$ Kandungan oksigen awal (sebelum inkubasi) (mg/l)

$\mathrm{N}=$ Waktu inkubasi (jam)

$\mathrm{PQ}=$ Photosynthetic quotient (lamun 1,25 dan fitoplankton 1,20) (Kaladharan dan Raj, 1989; Ryther, 1956).

Konversi nilai penyerapan karbon disetarakan (equivalen) ke dalam bentuk karbondiokasida $\left(\mathrm{CO}_{2}\right)$ atau bikarbonat $\left(\mathrm{HCO}_{3}^{-}\right)$. Hal tersebut disebabkan karena pada kenyataanya, karbon yang diserap oleh lamun selain bentuk karbondioksida juga dalam bentuk bikarbonat tergantung dari nilai keasaman dan suhu perairan. Untuk mengkonversi nilai produktivitas

primer ke dalam bentuk $\mathrm{CO}_{2}$ yang diserap, maka setiap 1 gram karbon yang diproduksi, menggunakan 3,67 gram $\mathrm{CO}_{2}$ atau menggunakan 5,08 gram $\mathrm{HCO}_{3}$.
Konsenrasi kalsium karbonat dan bikarbonat di air didapatkan dengan menggunakan formula (APHA, 1995) :

$\mathrm{CaCO}_{3}$ atau $\mathrm{HCO}_{3}(\mathrm{ppm})=\frac{A m l \times N \text { titran } \times \frac{100}{2} \times 1000}{V \mathrm{ml}}$

dimana :

$\mathrm{A}=$ Volume titran $(\mathrm{ml})$ yang digunakan $\left(\mathrm{PP}\right.$ untuk $\mathrm{CaCO}_{3}$ dan BCG untuk $\left.\mathrm{HCO}_{3}^{-}\right)$

$\mathrm{N}=$ Normalitas titran $(0,02 \mathrm{~N})$

$\mathrm{V}=$ Volume sampel $(25 \mathrm{ml})$

Semua daun lamun yang telah digunakan pada botol diukur luasnya. Nilainya digunakan untuk mengetahui kemampuan penyerapan karbon per luas daun lamun. Daun lamun diletakkan pada kertas yang telah diberi garis batas (bingkai) dengan ukuran $15 \mathrm{~cm} \mathrm{x} 15 \mathrm{~cm}$, kemudian dipindai (di-scan). Garis batas dimasukkan agar luas bingkai dapat diketahui. Selanjutnya gambar hasil scan dianalisis menggunakan software ImageJ untuk mendapatkan nilai persen tutupan daun lamun terhadap luas bingkai. Nilai persen tutupan daun lamun dikali dengan luas bingkai sehingga didapatkan luas daun lamun. Rumus yang digunakan adalah :

$L_{d}=P_{d} X L_{b}$

Dengan :

$\mathrm{L}_{\mathrm{d}}=$ Luas daun $\left(\mathrm{cm}^{2}\right) \mathrm{L}_{\mathrm{b}}=$ Luas bingkai $\left(\mathrm{cm}^{2}\right)$

$\mathrm{P}_{\mathrm{d}}=$ Persentase tutupan daun lamun terhadap bingkai (\%)

Selanjutnya daun lamun yang telah difoto kemudian dikeringkan menggunakan oven dengan suhu $40^{\circ} \mathrm{C}$ sampai berat konstan. Daun lamun kering ditimbang menggunakan timbangan digital dengan ketelitian 0,001 gram untuk mengetahui biomassanya. Biomassa daun digunakan untuk mengetahui kemampuan 
penyerapan karbon oleh lamun per biomassa. Sampel lamun $T$. hemprichii yang digunakan menujukkan variasi karakter. Biomassa basah berkisar 1,484-2,500 gram berat basah, biomassa kering 0,057-0,085 gram berat kering dan luas daun berkisar $61,5-94,8 \mathrm{~cm}^{2}$ (Tabel 1).

Tabel 1. Biomassa dan luas daun (rata-rata \pm SD) sampel $T$. hemprichii yang diinkubasi pada beberapa kedalaman

\begin{tabular}{ccccc}
\hline $\begin{array}{c}\text { Kedalaman } \\
(\mathrm{cm})\end{array}$ & $\begin{array}{c}\text { Jumlah } \\
\text { Ulangan }\end{array}$ & $\begin{array}{c}\text { Biomassa Basah } \\
(\mathrm{gbb})\end{array}$ & $\begin{array}{c}\text { Biomassa Kering } \\
(\mathrm{gbk})\end{array}$ & $\begin{array}{c}\text { Luas Daun 2 } \\
\text { sisi }\left(\mathrm{cm}^{2}\right)\end{array}$ \\
\hline 50 & 5 & $2,500 \pm 0,060$ & $0,085 \pm 0,021$ & $94,8 \pm 8,3$ \\
100 & 5 & $1,864 \pm 0,057$ & $0,075 \pm 0,018$ & $65,8 \pm 7,3$ \\
150 & 5 & $2,188 \pm 0,132$ & $0,085 \pm 0,039$ & $92,8 \pm 21,1$ \\
200 & 5 & $1,484 \pm 0,110$ & $0,057 \pm 0,013$ & $61,5 \pm 5,8$ \\
250 & 5 & $1,572 \pm 0,110$ & $0,060 \pm 0,017$ & $67,6 \pm 9,0$ \\
\hline
\end{tabular}

\section{HASIL DAN PEMBAHASAN}

\section{Parameter Oseanografi}

Parameter oseanografi yang terukur mengalami perubahan dari awal ke akhir inkubasi, kecuali salinitas. Nilai $\mathrm{pH}$, suhu perairan dan intensitas cahaya mengalami peningkatan, sedangkan alkalinitas mengalami penurunan (Tabel 2 dan Gambar 3).

Tabel 2. Faktor lingkungan saat penelitian

\begin{tabular}{lll}
\hline \multirow{2}{*}{ Parameter } & Waktu & \\
\cline { 2 - 3 } & Awal Inkubasi & Akhir Inkubasi \\
\hline $\mathrm{pH}$ & $8,1(8,1-8,2)$ & $8,2(8,1-8,2)$ \\
Salinitas $(\mathrm{ppt})$ & 32 & 32 \\
Suhu $\left({ }^{\circ} \mathrm{C}\right)$ & $31(30-31))$ & $32(32-33)$ \\
Alkalinitas total perairan $(\mathrm{ppm})$ & $306(298-314)$ & $275(234-300)$
\end{tabular}

Catatan : Nilai pada $\overline{\mathrm{pH}}$, suhu dan alkalinitas total merupakan nilai rata-rata dan angka di dalam kurung merupakan nilai kisaran

Intensitas cahaya tertinggi pada permukaan perairan terjadi pada jam 13.00 WITA (Gambar 3a). Sedangkan berdasarkan kedalaman, intensitas cahaya mengalami penurunan seiring dengan bertambahnya kedalaman. Pada kedalaman $50 \mathrm{~cm}$, intensitas cahaya didapatkan sebesar 36.262 lux pada awal inkubasi (jam 09.00 WITA), dan meningkat menjadi 66.532 lux pada akhir inkubasi (jam 12.00 WITA). Pada kedalaman $250 \mathrm{~cm}$, intensitas cahaya sebesar 6.745 lux pada awal inkubasi dan 20.456 lux pada akhir inkubasi (Gambar 3b).

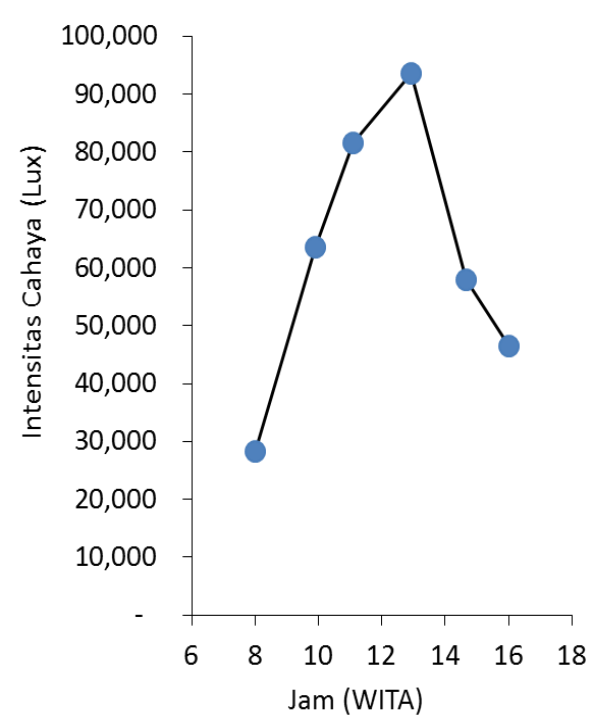

a

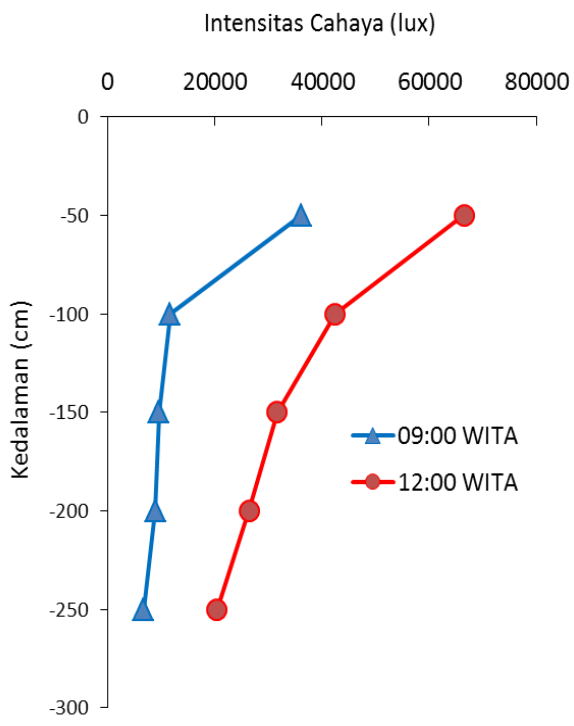

b

Gambar 3. Intensitas cahaya terukur. (a) Profil intensitas cahaya permukaan perairan berdasarkan waktu, dan (b) Profil intensitas cahaya berdasarkan kedala 


\section{Serapan karbon}

Serapan karbon lamun $T$. hemprichii menunjukkan variasi antar kedalaman. Serapan karbon per tunas berkisar antara 0,928-1,476 $\mathrm{mgCO}_{2} /$ tunas/jam (Gambar 4a). Pola yang sama ditunjukkan oleh serapan karbon per biomassa dengan kisaran 10,647-25,745 $\mathrm{mgCO}_{2} / \mathrm{g}$ berat kering/jam (Gambar 4b) dan serapan karbon per luas daun dengan kisaran 0,010-0,024 $\mathrm{mgCO}_{2} / \mathrm{cm}^{2} / \mathrm{jam}$ (Gambar 4c).

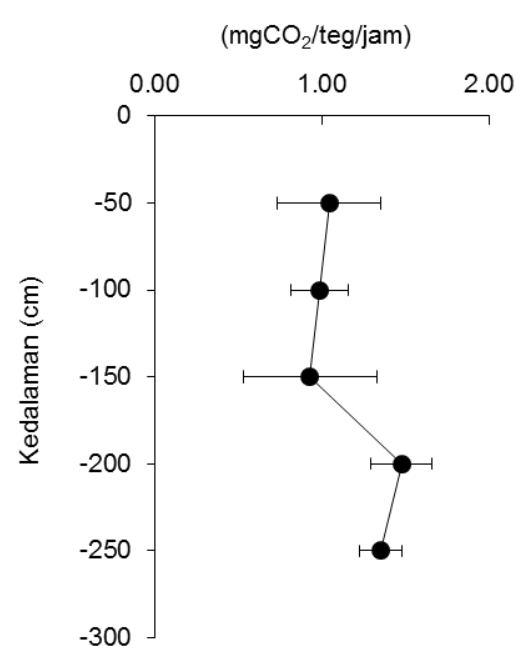

a

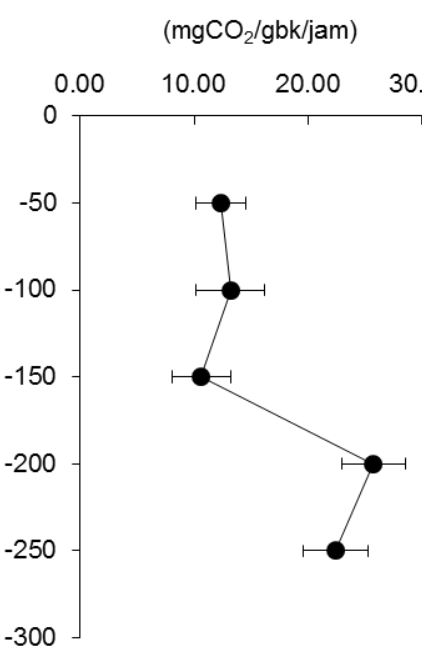

b

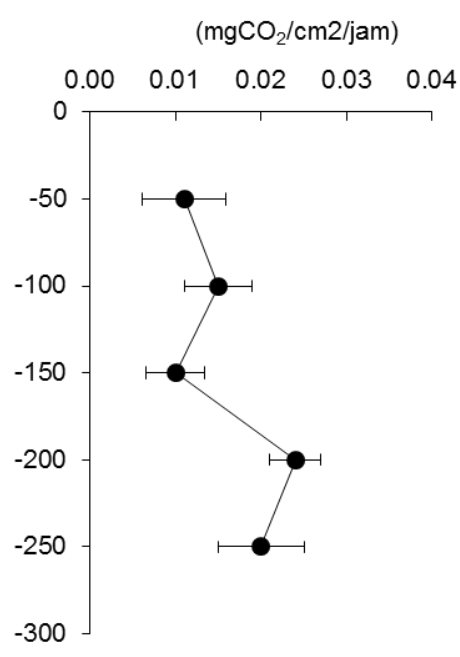

C

Gambar 4. Profil serapan karbon oleh T. hemprichii berdasarkan kedalaman perairan. (a) per tunas, (b) per biomassa kering, dan (c) per luas daun.

Serapan karbon oleh lamun T. hemprichii menunjukkan bahwa pada kedalaman $50 \mathrm{~cm}$ dengan intensitas cahaya tertinggi, tidak menyebabkan serapan karbon tertinggi pula. Hal tersebut kemungkinan merupakan fenomena photo inhibition, dimana intensitas cahaya yang terlalu tinggi akan menghambat proses fotosintensis pada lamun $T$. hemprichii, sebagaimana yang terjadi pada plankton (Nontji, 2008). Serapan karbon tertinggi ditemukan pada kedalaman $200 \mathrm{~cm}$ dengan intensitas cahaya 8.982 lux pada jam 090.00 WITA dan 26.457 lux pada jam 12.00 WITA, yang berarti bahwa proses fotosintesis berlangsung secara optimum pada kedalaman tersebut. Pada kondisi daun T. hemprichii terpapar sinar matahari secara langsung pada siang hari di daerah intertidal, dapat menyebabkan peningkatan nilai photo inhibition (Beer et al., 2006). Strydom et. al. (2017) menemukan adanya penurunan respon pertumbuhan $H$. ovalis pada kedalaman 3 meter sebagai akibat penurunan kuantitas cahaya.

Disamping fenomena photo inhibition, kemungkinan lainnya adalah adaptasi yang dilakukan oleh lamun dengan meningkatkan jumlah klorofil sebagai respon menurunnya cahaya pada kedalaman $200 \mathrm{~cm}$. Penelitian yang dilakukan oleh Cumming dan Zimmerman (2002) memperlihatkan bahwa konsentrasi klorofil lebih tinggi pada kedalaman dimana cahaya mulai berkurang. Penelitian tersebut menunjukkan bahwa pada jenis Thalassia testudinum, jumlah klorofil pada intensitas cahaya 1100 $\mu \mathrm{mol} / \mathrm{m}^{2} /$ detik sebanyak $0,52 \mathrm{mg} / \mathrm{gbk}$, meningkat menjadi $0,84 \mathrm{mg} / \mathrm{bk}$ pada intensitas cahaya 700 $\mu \mathrm{mol} / \mathrm{m}^{2} /$ detik. Pada jenis Zostera marina, jumlah klorofil pada intensitas cahaya $300 \mu \mathrm{mol} / \mathrm{m}^{2} /$ detik sebanyak $1,74 \mathrm{mg} / \mathrm{gbk}$ dan meningkat pada intensitas cahaya $50 \mu \mathrm{mol} / \mathrm{m}^{2} /$ detik menjadi $2,50 \mathrm{mg} / \mathrm{gbk}$.

Karbon yang diserap oleh lamun pada proses fotosintesis dapat berupa karbodioksida $\left(\mathrm{CO}_{2}\right)$ atau bikarbonat $\left(\mathrm{HCO}_{3}{ }^{-}\right)$(Larkum et al., 2006). Salah satu faktor yang mempengaruhi bentuk karbon yang diserap oleh lamun adalah tingkat keasaman $(\mathrm{pH})$ air laut, yang berpengaruh terhadap ketersediaan kedua bentuk karbon tersebut. Pada $\mathrm{pH}$ perairan 8,2 maka ketersediaan karbondioksida terbatas sehingga lamun lebih banyak menyerap bikarbonat untuk proses fotosintesis (Larkum et al., 1989). Tingkat keasaman air laut pada saat penelitian rata-rata 8,1 pada awal inkubasi dan meningkat menjadi 8,2 pada akhir inkubasi. Berdasarkan pada teori di atas maka kemungkinan penyerapan karbon oleh lamun $H$. ovalis lebih banyak dalam bentuk bikarbonat dibanding karbondioksida.

Jika serapan karbon dikonversi kedalam bentuk bikarbonat maka nilainya akan lebih tinggi dibanding dalam bentuk karbondioksida. Perbedaan tersebut disebabkan karena berat molekul keduanya berbeda. Nilai serapan bikarbonat sekitar 1,4 kali nilai serapan karbondioksida. Indikator adanya penggunaan bikarbonat ditunjukkan oleh menurunnya bikarbonat pada masing-masing botol sampel pada semua kedalaman. Rata-rata serapan karbon per tunas berkisar 1,286-2,046 $\mathrm{mgHCO}_{3}{ }^{-} /$tunas/jam, serapan karbon per biomassa berkisar 14,761-35,692 mgHCO$_{3}^{-}$ /gbk/jam dan serapan karbon per luas daun berkisar 0,014-0,033 $\mathrm{mgHCO}_{3}{ }^{-} / \mathrm{cm}^{2} / \mathrm{jam}$ (Tabel 3). 
Tabel 3. Serapan karbon lamun T. hemprichii dalam bentuk bikaronat (equivalen)

\begin{tabular}{llll}
\hline \multirow{2}{*}{$\begin{array}{l}\text { Kedalama } \\
\mathrm{n}(\mathrm{cm})\end{array}$} & \multicolumn{3}{l}{ Penyerapan Bikarbonat $\left(\mathrm{mgHCO}_{3}\right.$-/jam) } \\
\cline { 2 - 4 } & Per Tunas & $\begin{array}{l}\text { Per } \\
\text { Biomassa } \\
\text { (gbk) }\end{array}$ & $\begin{array}{l}\text { Per Luas } \\
\text { Daun }\left(\mathrm{cm}^{2}\right)\end{array}$ \\
\hline & $1,44 \pm 0,430$ & 8 & $0.015 \pm 0,00$ \\
-50 & $1,368 \pm 0,23$ & $18,267 \pm 4,13$ & $0,021 \pm 0,00$ \\
\hline & 6 & 1 & 6 \\
-100 & $1.286 \pm 0,55$ & $14,761 \pm 3,52$ & $0.014 \pm 0,00$ \\
& 2 & 1 & 5 \\
-150 & $2,046 \pm 0,25$ & $35,692 \pm 3,83$ & $0,033 \pm 0,00$ \\
-200 & 2 & 3 & 4 \\
& $1,875 \pm 0,17$ & $31,110 \pm 3,97$ & $0.028 \pm 0,00$ \\
-250 & 5 & 9 & 7 \\
\hline
\end{tabular}

Kandungan bikarbonat pada semua kedalaman di dalam botol sampel mengalami penurunan dengan nilai yang bervariasi. Penurunan terendah ditemukan pada kedalaman $250 \mathrm{~cm}$ yaitu sebesar $157 \mathrm{ppm}$ dan penurunan tertinggi ditemukan pada kedalaman $100 \mathrm{~cm}$ yaitu sebesar 185 ppm (Tabel 4). Penurunan bikarbonat tertinggi ditemukan pada kedalaman $100 \mathrm{~cm}$ yaitu sebesar $185 \mathrm{ppm}$ dan terendah pada kedalaman $250 \mathrm{~cm}$ yaitu 157 ppm. Pola penurunan nilai bikarbonat berdasarkan kedalaman sama dengan pola serapan karbondioksida dan serapan bikarbonat. Namun demikian, belum bisa disimpulkan bahwa serapan karbon lamun dalam proses fotosintesis semua dalam bentuk bikarbonat. Selain penurunan bikarbonat akibat penyerapan oleh lamun, kemungkinan lain juga bisa disebabkan oleh perubahan bentuk karbonat pada persamaan reaksi kimia, sebagai upaya mempertahankan keseimbangan pada air laut (sebagai buffer).

Tabel 4. Kandungan bikarbonat $\left(\mathrm{HCO}_{3}^{-}\right)$botol pada awal dan akhir inkubasi

\begin{tabular}{llll}
\hline \multirow{2}{*}{$\begin{array}{l}\text { Kedalaman } \\
(\mathrm{cm})\end{array}$} & \multicolumn{2}{l}{ Bikarbonat $(\mathrm{ppm})$} & $\begin{array}{l}\text { Penurunan } \\
(\mathrm{ppm})\end{array}$ \\
\cline { 2 - 3 } & $\begin{array}{l}\text { Awal } \\
\text { Inkubasi }\end{array}$ & $\begin{array}{l}\text { Akhir } \\
\text { Inkubasi }\end{array}$ & \\
\hline-50 & 287 & 116 & 171 \\
-100 & 269 & 84 & 185 \\
-150 & 278 & 108 & 179 \\
-200 & 258 & 98 & 160 \\
-250 & 287 & 130 & 157 \\
\hline
\end{tabular}

Sebagai perbandingan, penelitian La Nafie, et. al. (2013) menunjukkan kerapatan $T$. hemprichii di Gusung Bonebatang rata-rata (rata-rata \pm SD) sebesar $112 \pm 26$ tunas permeter persegi. Jika dikonversi ke kapasitas penyerapan karbon, maka jenis ini mampu menyerap sebesar $161,9 \quad \mathrm{mgCO}_{2} / \mathrm{m}^{2} / \mathrm{jam}$ pada kedalaman $50 \mathrm{~cm}$ dan $229,2 \mathrm{mgCO}_{2} / \mathrm{m}^{2} / \mathrm{jam}$ pada kedalaman $200 \mathrm{~cm}$, atau sebesar 116,8 mgHCO$_{3}$ $/ \mathrm{m}^{2} /$ jam pada kedalaman $50 \mathrm{~cm}$ dan $165 \mathrm{mgHCCO}_{3}$ $/ \mathrm{m}^{2} /$ jam pada kedalaman $200 \mathrm{~cm}$.

\section{KESIMPULAN}

Penyerapan karbon tertinggi oleh lamun T. hemprichii dalam proses fotosintesis terjadi pada kedalaman 200 $\mathrm{cm}$. Hubungan linear antara intensitas cahaya dan serapan karbon terjadi setelah kedalaman $200 \mathrm{~cm}$, dimana semakin rendah intensitas cahaya maka semakin rendah pula serapan karbon lamun.

\section{DAFTAR PUSTAKA}

American Public Health Association (APHA). 1995. Standard methods for the examination of water and wastewater. Washington DC.

Beer, S., Mtolera M., Lyimo T. \& Bjork M.. 2006. The photosynthetic performance of the tropical seagrass Halophila ovalis in the upper intertidal. Aquatic Botany 84: 367-371.

Cummings, M.E \& Zimmerman R.C.. 2002. Light harvesting and the package effect in the seagrass Thalassia testudinum banks ex koning and zosetera marina L.: optical constraints on photoaclimation. Aquatic Botani 75: 261-274.

Duarte, C.M. 2013. The role of seagrass in climate change mitigation and adaptation. The University of Western Australia and Spanish National Research Council, Bonn.

Gartside, P.S.D \& Smith, S.F. 2013. A review of mangrove and seagrass ecosystems and their linkage to fisheries and fisheries management. Food and Agriculture Organization of The United Nations, Regional Office For Asia and The Pacific, Bangkok.

Huang, Y., Lee, C., Chung, C., Hsiao, S. dan Lin, H. Carbon budgets of multispecies seagrass beds at Dongsha Island in the South China Sea. Mar. Env. Res. 106: 92-102.

Kaladharan, P. \& Raj, I.D. 1989. Primary production of seagrass Cymodocea serrulata and its contribution to productivity of Amini atoll, Lakshadweep Islands. Indian Journal of Marine Science 18: 215-216.

Kuriandewa, T.E. 2009. Tinjauan tentang lamun di Indonesia. Lokakarya Nasional I Pengelolaan Ekosistem Lamun: Peran Ekosistem Lamun dalam Produktivitas Hayati dan Meregulasi Perubahan Iklim. Jakarta, 18 November 2009.

La Nafie, Y.A., de los Santos, C.B., Brun, F.G., Mashoreng, S., van Katwijk, M.M \& Bouma, T.J. 2013. Biomechanical response of two fastgrowing tropical seagrass species subjected to in situ shading and sediment fertilization. J. Exp. Mar. Biol. Ecol. 446: 186-193.

Larkum A.W.D., Roberts G., Kuo J \& Strother S.. 1989. Gaseous movement in seagrasses. In AWD Larkum, AJ McComb and SA Shepherd (eds.), Biology of Seagrasses: A treatise on the biology of seagrasses with special reference to the Australasian region. Elsevier Pub. Co, Amsterdam. 
Larkum, A.W.D., Drew E.A. \& Ralp P.J.. 2006. Photosynthesis and Metabolism in Seagrasses at The Celluler Level. Di dalam: Larkum A.W.D, Orth R.J., Duarte C.M, editor. Seagrasses: Biology, Ecology and Conservation. Springer. Dordrecht.

Lymo, L.D. 2016. Carbon sequestration processes in tropical seagrass beds. Thesis. Stockholm University. Malmo Sweden.

Marba, N., Arias-Ortiz, A., Masque, P., Kendrick, G.A., Mazarrasa, I., Bastyan. G.R., GarciaOrellana, J. dan Duarte, C.M. 2015. Impact of seagrass loss and subsequent revegetation on carbon sequestration anh stocks. Journal of Ecology 103: 296-302.

Mashoreng, S. 2017. Perubahan penyerapan karbon di Pulau Barranglompo Kurun Waktu Tahun 20012016. Makalah Seminar Nasional Tahunan XIV Hasil Penelitian Perikanan dan Kelautan, tanggal 22 Juli 2017 di Jogjakarta.

Mateo, M.A., Renom, P., Hemminga, M.A. \& Peene, J. 2001. Measurement of seagrass production using the $13 \mathrm{C}$ stable isotope comapre with calssical O2 and 14C methods. Mar. Ecol. Prog. Ser. 223: 157-165.

Nontji, A. 2008. Plankton Laut. Lembaga Ilmu Pengetahuan Indonesia (LIPI) Press, Jakarta.

Ondiviela, B., Losada, I.J. Lara, J.L, Maza, M, Galván, C, . Bouma, T.J \& Belzen, J.V. 2014. The role of seagrasses in coastal protection in a changing climate. Coastal Engineering 87: 158-168.

Parsons, T.R., Maita, Y. \& Lalli, C.M. 1984. A Manual Of Chemical and Biological Methods For Seawater Analysis. Pergamon Press, Oxford.

Ryther, J. H. 1956. The measurement of primary production. Limnology and Oceanography 1: 72-84.

Silva, J., Sharon Y., Santos R. \& Beer S.. 2009. Measuring seagrass photosynthesis: methods and applications. Aquatic Botani 7: 127-141.

Strydom, S., McMahon K. \& Lavery P.S.. 2017. Response of the seagrass Halophila ovalis to altered light quality in a simulated dredge plume. Marine Pollution Bulletin 121: 323-330. 